(i)

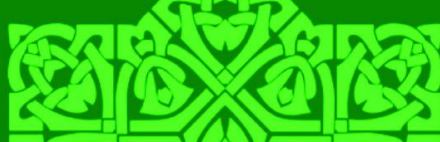
tह

Muhammad Yusuf, Baharuddin, Mardan The Quranic Hermeneutics Approach to Gender Equality in Amina Wadud Muhsin's View

A. Zamakhsyari Baharuddin التظاهر بالشعار ات القومية في شعيرة الحج و العمرة

Andi Muhammad Ridwan, Baso Pallawagau Falsafah Al-Wujudiyyah Al-Sufiyyah: Asluha Al-Dini wa Manqif Al-Ulama Minha

Muhammad Widus Sempo, Norita Binti Md Norwawi, Hasyim Haddade, Yousuf Mahbubul Islam, Noorhayati Binti Hasyim Unbelievers' Mental Model and Behavioural Disorders Based on Their Queries in The Al-Baqarah Chapter

Sri Sunantri, Achmad Abubakar, Kamaluddin Abu Nawas, Firdaus Methodology of Interpretation of Muhammad Amin Al-Syinqiti

Amirullah, Andi Achruh AB. Pasinringi, Rahmawansyah Sahib The Transformation of The Muamalah Fiqh Akad at Saga Abepura-Papua Mall During The Covid 19 Pandemic

Irwan Misbach Siri'Na Pacce Culture in Retailer Based on Islamic Perspective Business Ethics

Abd. Rahman R Family Resilience in Islamic Perspective (A Case Study of Parent and Child Interaction Behavior in The District of Somba Opu Gowa)

Vol. 20 No. $2 / 2020$ 


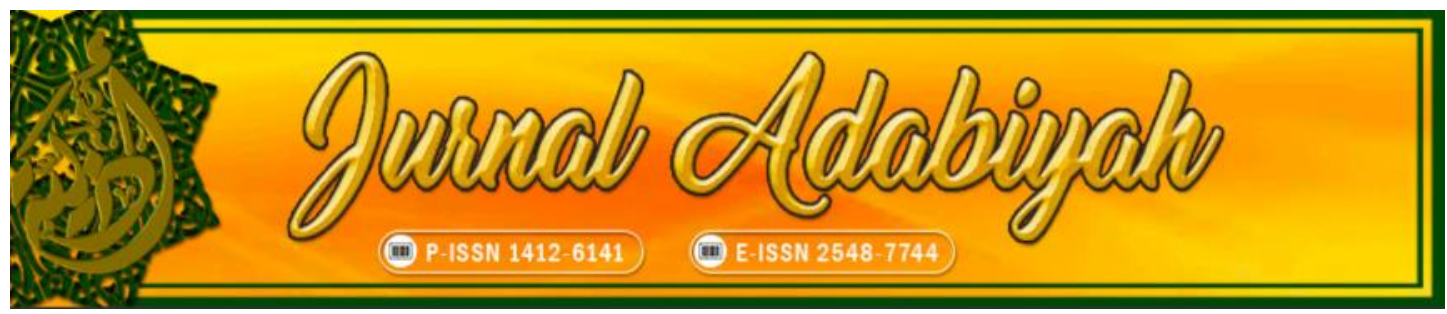

Theme: Islamic Studies

VOLUME 20 NO. 2 DECEMBER 2020

\section{EDITOR-IN-CHIEF}

Barsihannor, Alauddin State Islamic University, Indonesia

\section{INTERNATIONAL EDITORIAL BOARD}

Nuri Emmiyati, Alauddin State Islamic University, Indonesia

Minako Sakai, Australian National University (ANU), Australia

Abd Rauf Muhammad Amin, Fakulti Syariah Kupu SB Brunei Darussalam, Brunei Darussalam

Muhammad Widus Sempo, Universiti Sains Islam Malaysia, Malaysia

Salih Yousif Sharaf Mohamed, Al-Gazera University, Sudan

Aishah Waenaha Waemamah, Academy of Islamic and Arabic Studies Princess of Naradhiwas University - Thailand, Thailand

\section{EXECUTIVE EDITOR}

Umar Thamrin, Alauddin State Islamic University, Indonesia

\section{MANAGING EDITOR}

Nasrum, Alauddin State Islamic University, Indonesia

\section{EDITORS}

Rosmah Tami, Alauddin State Islamic University, Indonesia Haniah Haniah, Alauddin State Islamic University, Indonesia Zaenal Abidin, Alauddin State Islamic University, Indonesia

Awaluddin Syamsu, Universitas Muslim Indonesia

Ahmadi Usman, UIN Syarif Hidayatullah Jakarta, Indonesia

Baso Pallawagau, Alauddin State Islamic University, Indonesia

Muhammad Azwar, UIN Syarif Hidayatullah Jakarta, Indonesia

Muh. Saleh Syamsuri, Alauddin State Islamic University, Indonesia

Andi Satrianingsih, Muhammadiyah University, Indonesia

Syahruni - Junaid, Alauddin State Islamic University, Indonesia

Rabiatul Adawiah, Majene Islamic State College, West Sulawesi, Indonesia, Indonesia

Chusnul Chatimah Asmad, Alauddin State Islamic University, Indonesia

Nur Arifin, Alauddin State Islamic University, Indonesia

\section{IT SUPPORT}

Taufiq Mathar, Alauddin State Islamic University, Indonesia

\section{LANGUAGE ADVISOR}

Kustiwan Syarief, UIN Syarif Hidayatullah Jakarta, Indonesia Muh. Saleh Syamsuri, Alauddin State Islamic University, Indonesia

\section{COVER DESIGNER}

Nur Arifin 


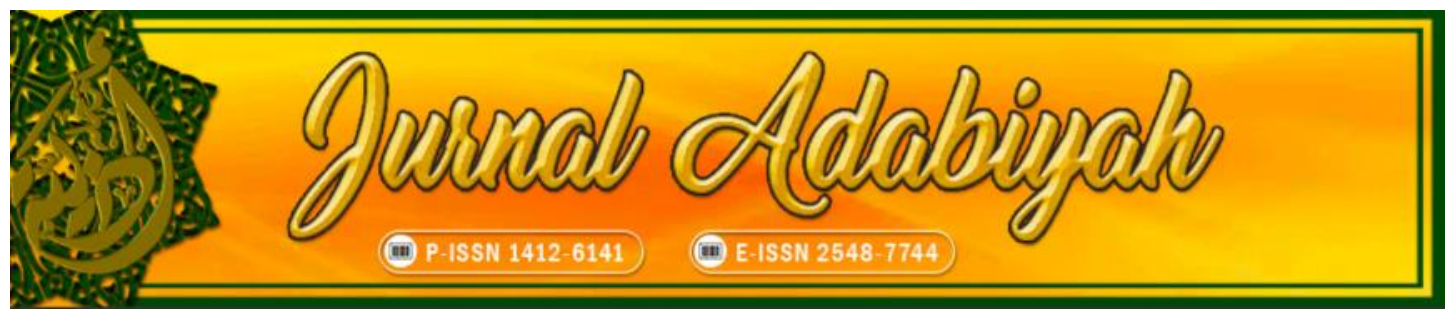

\section{Jurnal Adabiyah:}

This journal receives a national accreditation from Ministry of Research, Technology, and Higher Education Republic of Indonesia, Nomor 10/E/KPT/2019 on April 4, 2019 with the SINTA score: S2.

The Journal has been published by the Faculty of Adab and Humanity of Alauddin State Islamic University, Makassar, since 1997 and has been online since 2016 with the main themes on Humanities and Islamic Studies with the emphasis on interdisciplinary and intertextuality approach.

This journal are published twice a year, on June and December. The themes related to Islamic Studies are textual studies, scriptural traditions, Islamic law, and theology; and those related to Humanities are language, literature, history, and culture.

The journal of Humanities and Islamic Studies will provide the online collection of articles from 1997 up to now. The most updated information can be found on the website. 


\section{Table of Contents}

Muhammad Yusuf, Baharuddin, Mardan

214-237

The Quranic Hermeneutics Approach to Gender Equality in Amina Wadud Muhsin's View

A. Zamakhsyari Baharuddin

التظاهربالشعارات القومية في شعيرة الحج والعمبرة

261-285

Andi Muhammad Ridwan, Baso Pallawagau

Falsafah Al-Wujudiyyah Al-Sufiyyah: Asluha Al-Dini wa Mauqif AlUlama Minha

Muhammad Widus Sempo, Norita Binti Md Norwawi, Hasyim Haddade, Yousuf Mahbubul Islam, Noorhayati Binti Hasyim ................... 286-299 Queries in The Al-Baqarah Chapter

Sri Sunantri, Achmad Abubakar, Kamaluddin Abu Nawas, Firdaus. 300-319 Methodology of Interpretation of Muhammad Amīn Al-Syinqiti

Amirullah, Andi Achruh AB. Pasinringi, Rahmawansyah Sahib

The Transformation of The Muamalah Fiqh Akad at Saga Abepura-Papua Mall During The Covid 19 Pandemic

Irwan Misbach

Siri' Na Pacce Culture in Retailer Based on Islamic Perspective Business Ethics

Abd Rahman R

Family Resilience in Islamic Perspective (A Case Study of Parent and Child Interaction Behavior in The District of Somba Opu Gowa) 


\title{
THE TRANSFORMATION OF THE MUAMALAH FIQH AKAD AT SAGA ABEPURA-PAPUA MALL DURING THE COVID 19 PANDEMIC
}

\author{
Amirullah $^{1}$, Andi Achruh AB. Pasinringi ${ }^{2}$, Rahmawansyah Sahib ${ }^{3}$ \\ IAIN Fattahul Muluk Papua, Indonesia ${ }^{1}$ \\ Universitas Islam Negeri Alauddin Makassar, Indonesia ${ }^{2}$ \\ IAIN Fattahul Muluk Papua, Indonesia ${ }^{3}$ \\ Email: amirullahnafis@gmail.com ${ }^{1}, \underline{\text { andiachruh@gmail.com }}{ }^{2}$, \\ rahmawansyahiainpapua@gmail.com ${ }^{3}$
}

\begin{abstract}
This article comes with a new perspective to understand the community transactions dynamics at the Saga Abepura Mall, Papua (MSA). The Covid-19 period challenges MSA managers in carrying out contract transformation. This article takes a close look at the changes in the muamalah fiqh agreement from offline to online, significantly transforming contract transactions at MSA during the Covid-19 pandemic. Two points are studied. First, muamalah fiqh transactions concerning contract transformation. Second, an analysis of contract changes. The focus of this article is on changing the old contract to the new contract. This article considers that a new contract is allowed in muamalah jurisprudence as long as there is no opposition with the AlQur'an and Al-Hadith. This article seeks answers to questions using observational data and interviews. The interview involved seven informants. They are four MSA employees and three customers. Transactions in a new contract do not mean replacing the old contract law. Creating a muamalah contract transformation does not have to eliminate other covenants. The existence of transforming an online buying and selling contract gave birth to a new form of contract at MSA, namely the order contract. First, the salam contract is the contract when the goods are paid for in advance, while the isthisnah contract was the contract when the order is paid when the good is in hand. Thus, all agents, MSA managers, customers, and employees should pay attention to contract transformation.
\end{abstract}

Keywords: Transformation; Akad; Muamalah; The Saga Abepura-Papua Mall 
الملخص - المص

تأتي هذه المقالة مع منظور جديد لفهم ديناميكيات المجتمع في

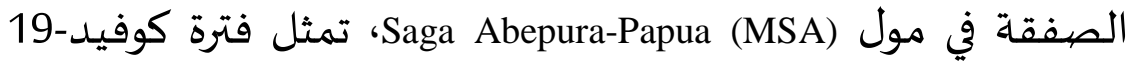
تحديات لمديري المول في تنفيذ تغيير العقد. تنظر هذه المقالة نظرة

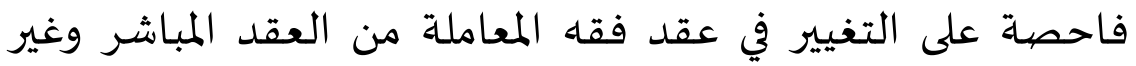
المباشر عبر الإنترنيت في المول فترة كوفيد-19. هناك شيئان مهمانيان يتم دراستهما الأول صفقة فقه المعاملة المتعلقة بتغيير العقد فئل والثاني

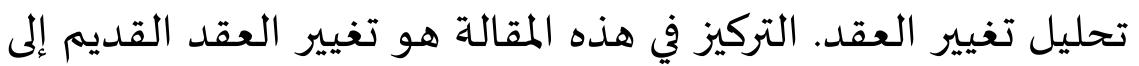

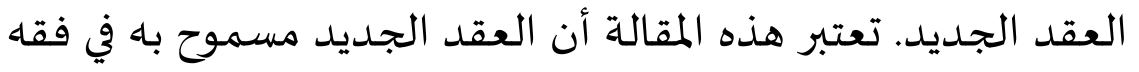

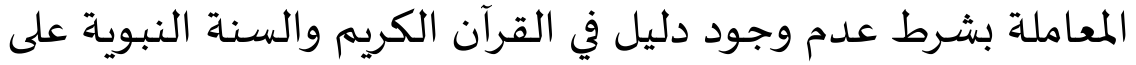

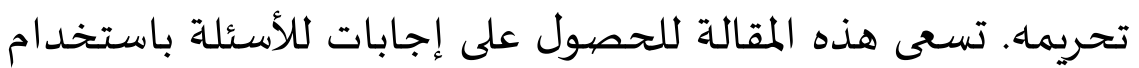

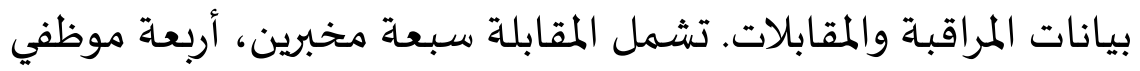

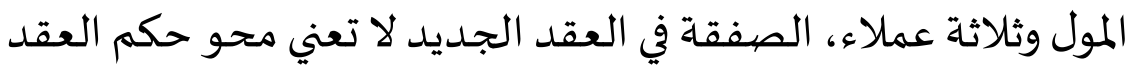

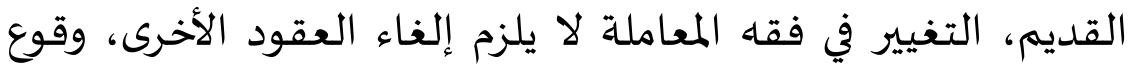

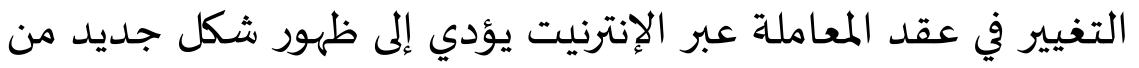

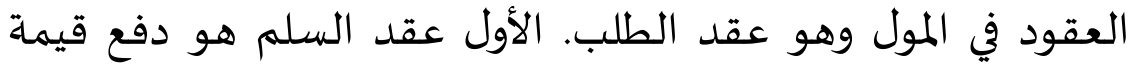

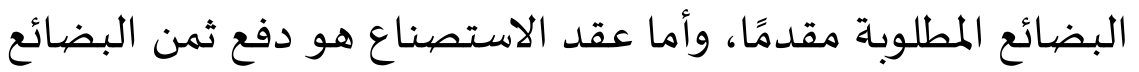
المطلوبة في النهاية عند استلام الطلب. وهكذا كل الأطراف من مديري المول والعملاء والموظفون يهتمون بتغيير العقد.

الكلمات الدالة: التغيير، عقد فقاء المعاملة، مول Saga Abepura-Papua

(MSA)

\begin{abstract}
Abstrak
Artikel ini hadir dengan perspektif baru untuk memahami dinamika masyarakat dalam bertransaksi di Mall Saga Abepura-Papua (MSA). Masa Covid-19 memberikan tantangan terhadap pengelola MSA dalam melakukan transfomasi akad.Artikel ini melihat dari dekat kaitan perubahan akad fikih muamalah dari offline ke online khususnya bagaimana transformasi akad bertransaksi di MSA pada masa pandemi covid-19. Ada dua hal penting yang dikaji. Pertama, transaksi fikih muamalah tentang transformasi akad. Kedua, analisis perubahan akad.
\end{abstract}


The Transformation of The Muamalah Fiqh Akad at Saga Abepura-Papua Mall During the Covid 19 Pandemic

Fokus dalam artikel ini adalah perubahan akad lama kepada akad baru. Artikel ini memandang bahwa akad baru dibolehkan dalam fikih muamalah asalkan tidak ada dalil Alqur'an dan Alhadis yang melarangnya. Artikel ini mencari jawaban atas pertanyaan-pertanyaan dengan menggunakan data observasi dan wawancara. Wawancara melibatkan tujuh informan. Empat orang karyawan MSA dan tiga orang konsumen. Transaksi dalam akad baru bukan berarti manghapus hukum akad yang telah lama. Menciptakan transformasi akad muamalah tidak harus menghilangkan akad-akad yang lainnya. Adanya transformasi akad jual beli online melahirkan bentuk akad baru di MSA, yakni akad pesanan. Pertama akad salam adalah pembayaran barang pesanan yang di bayar diawal, sedangkan akad isthisnah adalah pembayaran barang pesanan yang dilakukan diakhir yakni ketika pesanan sudah di tangan. Dengan demikian semua pihak, pengelola MSA, pelanggan dan karyawan memperhatikan transformasi akad.

Kata kunci: Transformasi; Akad; Fikih muamalah; Mall Saga Abepura-Papua.

\section{A. Introduction}

Papua is one of Indonesia's provinces with the highest incidence of transmission of the coronavirus disease (Covid-19) in Indonesia. The transmission of the disease harms local economic growth. Furthermore, the local government tried to manage the situation with the Governor of Papua's regulation, Number: 440/5168/ SET, concerning the prevention, control, and handling of coronavirus disease (Covid19). This regulation has brought implications and worsens the economical situations because people have to limit their activities.

Covid-19 forces people to remain silent, "stay at home." It can be understood that offline economical transactions are decreasing. Business activities such as street vendors, shops, restaurants, café, hotels, supermarkets, and malls, especially in Jayapura experience a significant visitor shortage. However, there is something different from Mall Saga Abepura (MSA) Papua, which shows a fortune during the pandemic situation. It can be seen from Ibl's statement that MSA has no employees being laid off, and the economic growth increases significantly. It is inversely proportional to the Ramayana Mall and the Jayapura Mall in the city of Jayapura, which have decreased the number of employees. ${ }^{2}$

The Saga Abepura Mall experiences a blessing during the covid-19 period, marked by stable incomes and laid-off employees' absence. The blessing begins with a change in the "transformation" of the contract. The contract's changing is the manager and customers' request, especially "loyal customers," as mentioned by Ibl. ${ }^{3}$ It

\section{${ }^{1}$ See the official data in https://covid19.go.id/peta-sebaran, November 2020.}

${ }^{2}$ Ita (Perempuan, 31 Tahun, Karyawan Mall Saga Abepura), wawancara, AbepuraPapua, 26 Mei 2020.

${ }^{3}$ Ibl (Pria, 35 Tahun, Karyawan Mall Saga Abepura. "Wawancara, Abepura-Papua," 
can be seen from the MSA management that there is an emotional relationship between managers and consumers. The transformation of the contract is from offline to online, especially for micro consumers. As Mrs. Ita admits that shopping offline is more challenging to maintain during the Covid-19 pandemic. Both customers and sellers are fear of being exposed to Covid-19 and government regulation. Thus, an online transaction is preferable.

Online transactions in the business world are not new. Several online shops, such as Lazada, Shopee, Tokopedia, already exist in Indonesia before the coming of Covid-19. However, these online shops only provide service, and they are not the owner of the product. So, online shopping in MSA is new something. Because it was different from the other online shop, it was the product owner and provided service. Absolutely, the innovation of MSA beneficial, especially for micro consumers. The application of online transactions in MSA makes customers more comfortable to access the desired products. The MSA promotes its products through Whatsapp and Facebook applications. Both applications are the preferable applications for MSA managers because it is the most accessible to consumers. As shown in the Papua Central Statistics Agency data, Papua's economy in the second quarter of 2020 increases by $4.52 \%$.

The main concern of this article is to understand the Muslim consumers. The BPS data shows that the number of Muslims in the District of Abepura and Heram is $55 \%$, while $45 \%$ is non-Muslims. Thus it is understood that Muslims have a religious understanding in a transaction. In the view of Umar ibnu Khatab states that:

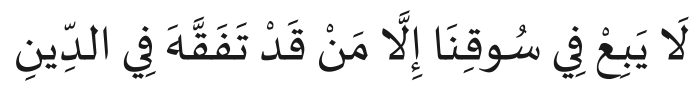

The meaning:

"Do not sell in this market traders who do not understand dien (muamalat)". ${ }^{4}$

Apart from the arguments above, another narration comes from Imam Malik. He ordered the rulers to gather all traders and market people to test them one by one about the halal and haram law on buying and selling. He forbade people to enter the market and told them to study muamalat fiqh. A person who understands the muamalat fiqh was allowed to enter the market, Tanbih Al Ghafilin. Then it is also narrated by AbuLaits, who said:

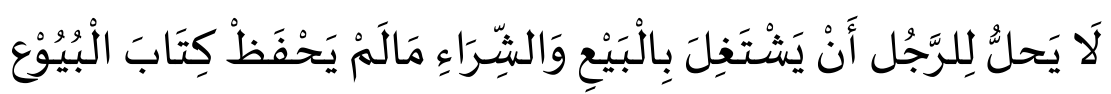

The meaning:

"An illegitimate man makes a sale and purchase contract while he has not mastered the fiqh chapter of buying and selling."

The opinions above illustrate that it is essential to understand the muamalat fiqh, especially about the economical transaction. ${ }^{5}$

2020.

${ }^{4}$ See https://republika.co.id/berita/qcq4ub430/umar-bin-khattab-usir-pedagang-yangtak-paham-fiqih-muamalat 
It is also understood that the study on the mass of Covid-19 tends to talk about several aspects related to education, health, culture, politics, and economy. Previous studies show that the pandemic era causes difficulties in finding a job and affording daily life (Silpa Hanoatubun: 1). ${ }^{6}$ Furthermore, Indra Rhmtullah explains that health insurance for workers is a necessity that must be fulfilled by entrepreneurs because it is part of Human Rights (HAM) ${ }^{7}$. Meanwhile, Agus Purwanto et.al states from the educational aspect, that Covid-19 has brought a significant impact to the teaching and learning process. ${ }^{8}$ Bank Indonesia (BI) also notes the increase of digital transactions and decreased cash transactions during the coronavirus pandemic. Furthermore, Minister of Trade Agus Supamanto said that Covid-19 had had a significant impact on small units, including traders who experience a decrease of $39 \%$ on average.

This study aims to complement the existing literature on the relation between the Covid-19 pandemic and economic transaction, particularly in Mall Saga AbepuraPapua. This study was based on the argument that the Covid-19 in the Abepura district transform its transactions due to the Covid-19 pandemic.

\section{B. Literature Review}

\section{Previous Studies}

Since the Covid-19 period, businesses have transformed their transactions to avoid customers. This case is illustrated in various studies. The previous article tends to examine the "offline" aspects of the digital business. This article tries to understand the transformation of the contract from the perspective of muamalah fiqh. It differs from previous studies. As it is shown in the literature review. First, online platformbased business in Jakarta during the covid-19 period by Agus Purwanto et al. ${ }^{9}$ Second, Silpa Hanoatubun sees an economic aspect that aims to determine the impact of Covid-19 on the economy. ${ }^{10}$ Third, according to Larasati Dhinarti and Firda Amalia, information technology development has a real impact on business

${ }^{5}$ See https://republika.co.id/berita/qcq4ub430

${ }^{6}$ See https://ummaspul,e-journal.id/Edupsycouns/article/view/423

${ }^{7}$ Indra Rahmatullah, "Jaminan Hak Kesehatan Pekerja work From Office selama masa PSBB Covid-19” Andalah: Buletin Hukum \& Keadilan 4, no 1 (2020), p. 57.

${ }^{8}$ Agus Purwanto dkk, "Studi Eksploratif Dampak Pandemi Covid-19 terhadaap proses Pembelajaran Online di sekolah dasar", EduPsyCouns Jurnal Kajian Education, Pyschologi and Consuling 2 no. 2 (2020), p. 1.

${ }^{9}$ Eka Avianti Ayuningtyas,"Dampak Pandemi Covid-19 Terhadap Bisnis Dan Eksistensi Platform Online", Pengembangan Wiraswasta 22, no 1 (April 2020), p. 23.

${ }^{10}$ Silpa Hanoatubun, "Dampak Covid-19 Terhadap Perekonomian Indonesia", EduPsyCouns. no 1 (2020), p. 45. 
innovation. ${ }^{11}$ Fourth, an article written by Nurhayati discusses online shopping among students. ${ }^{12}$ Fifth, Dedy Ansari Harahap tests online shopping behavior in Indonesia. ${ }^{13}$

The various studies above tend to look at platform-based business transactions, business behavior, business innovation, online shopping, and dominant factors in online buying and selling during the Covid-19 period. Meanwhile, this article looks at the changing of the transactions. First, Abdul Aziz's research on Mura'Bah $A h$ financing in banks. ${ }^{14}$ Second, Asep Rozali's research looks at the Sharia banking product's characteristics to form regulation on Hukum Perikatan Nasional. ${ }^{15}$ Third, Ismail Nawawi states that the transformation of the muamalah contract in Islamic banking is based on Sharia principles. ${ }^{16}$

Meanwhile, other literature sees the theory of transformation in a different sense. According to Anthony Antoniades, giving the meaning of transformation is a process of gradual change so that it reaches the ultimate stage. Changing is made to respond to the external and internal elements through the process of duplicating or multiplying. ${ }^{17}$ It describes architectural transformation strategies. Some are external, and some are internal. Indicators can measure those internal concepts through the need for self-identity, changes in lifestyle, and the influence of technology. ${ }^{18}$

Whereas Habraken said that there are several reasons for transformations. Namely, first, the need for self-recognition. Second, the changing of lifestyle, structural formation in society, the influence of other cultures, and the emergence of discoveries. Third, the influence of new technology creates a sense of fashion, in

${ }^{11}$ Larasati Dhinarti, dan Firda Amalia, "E-commerce dalam perspektif fiqh muamalat", CIMAE, 2, no. 3 (2019), p. 162.

${ }^{12}$ Nurhayati, "Belanja Online Sebagai Cara Belanja di Kalangan Mahasiswa (Studi Kajian Budaya di Universitas Malikussaleh, Lhokseumawe, Aceh)", Anthropological, 1. no 2 (April 2017).

${ }^{13}$ Dedy Ansari Harahap, "Perilaku Belanja Online di Indonesia: Studi Kasus", JRMSI, 9. no. 2, (2018), p. 34.

${ }^{14}$ Jamal Abdul Aziz, “Transformasi Akad Bay' al-Murabah dari Konsep Fikih ke Produk Bank (Analisis Kritis Perspektif Fikih Muamalah)", Al-Manahij: Jurnal Kajian Hukum Islam, IAIN Purwokerto, Vol. 8 No. 2, 2014, p. 1.

${ }^{15}$ Asep Rozali, "Transformasi Akad Perbankan Syariah dalam Pembentukan Hukum Perikatan Nasional”, Wawasan Yuridika, 4. no. 1, (Desember 2019), p. 31.

${ }^{16}$ Ismail Nawawi, FIkih Muamalah Klasik dan Kontemporer; Hukum Perjanjian, Ekonomi, Bisnis dan Sosial (Ghalia Indonesia: Bogor, 2012), p.143.

${ }^{17}$ Anthony C. Antoniades, Poetics of Architecture (New York: Van Nostrand Reinhold, 2019), p. 23.

${ }^{18}$ Stephanie Jill Najoan, “Transformasi Sebagai Strategi Desain”, Media Matrasain, 8. no. 2. (Agustus 2011), p. 119-120. 
The Transformation of The Muamalah Fiqh Akad at Saga Abepura-Papua Mall During the Covid 19 Pandemic

which parts that can still be used technically (not yet reaching technological age) are forced to be replaced to follow the model. ${ }^{19}$

\section{Buying and Selling in OnlineTransaction}

Fiqh scholars have different views on buying and selling, but they have a similar substance. Sayyid Sabiq believes that buying and selling is the exchange of property for property, which is carried out based on willingness (ridla) or transferring property rights by obtaining other objects in exchange for the way ordered by syara. ${ }^{20}$ Furthermore, Hasbi al-Shiddieqy said that buying and selling is the ownership of something by receiving the price based on the seller's willingness and the buyer. ${ }^{21}$ Thus, buying and selling is transfer of ownership using a traditional medium of exchange. Etymologically, in fiqh terms buying and selling is called al-ba'i which means selling or replacing. Wahbah al-Zuhaily defines it as exchanging something for something else. The word al-ba'i in Arabic is the opposite of al-Syira (to buy). Thus, the word al-ba'i means selling, but it also means buying. ${ }^{22}$ Imam Hanafiyah's opinion states that buying and selling are exchanging property with other assets through a unique way that is $i j a b$ qabul (Ijab consent).

Another researcher, Muhammad Daud Ali, gives a comprehensive understanding of buying and selling, namely, the existence of muamalah fiqh principles. ${ }^{24}$ Meanwhile, Hendi sees that the sale and purchase contract is at the level of the gharar concept (ambiguity). According to him, firstly the concept of gharar is based on the subject, and secondly the concept of ghararis based on the object. ${ }^{25}$ The transformation of the contract carried out at MSA is based on the concept of buying and selling that is mutually agreeable and has muamalah principles and does not contain elements of obscurity in buying and selling, so this is not allowed. So, offline and online transaction pays attention to the principles of gharar.

The concept of buying and selling online or e-commerce is one of the internet products which is based on a computer network connection. ${ }^{26} \mathrm{E}$-commerce is a set of

${ }^{19}$ Habraken, N. J. Transformation of the Site (A Water Press: Cambridge, 1983), p. 21.

${ }^{20}$ SayyidSabiq, Fiqh al-Sunnah, (Qahirah: Dar al-FathLali'lami al-Arabi, 1990), p. 761.

${ }^{21}$ Hasbi al-Shiddiqy, Hukun-hukum fiqh Islam, (Semarang: Pustaka Rizki Putera, 1997), p. 336.

${ }^{22} \mathrm{Al}$-Zuhaily Wahbah, Al-Fiqh al-Islami wa Adillatuh (Damaskus: t.tp. 2005), p. 23.

${ }^{23} \mathrm{Al}$-Zuhaily Wahbah, Al-Fiqh al-Islami wa Adillatuh, p. 21.

${ }^{24}$ Muhammad Daud Ali, Hukum Islam (Jakarta: Raja GrafindoPersada, 2004), p. 132138.

${ }^{25}$ HendiSuhendi, Fiqh Muamalah (Jakarta: PT. Raja GrafindoPersada, 1997), p. 26.

${ }^{26}$ Imam Mustofa, Fiqih Muamallah Kontemporer (Jakarta: PT. GrafendoPersada, 2016). p. 30 . 
technologies, applications, and business processes. ${ }^{27}$ It can be grouped, namely, business to business e-commerce and business to consumer e-commerce. ${ }^{28}$ The challenges that arise in e-commerce activities are the object of transaction that are traded and the transferring mechanism ${ }^{29}$

The basic law of online buying and selling is the same as the buying and selling contract and the Salam contract. Those cases are allowed in Islam. However, there are several reasons declared as haram if the system is haram and if the goods or services that are prohibited. Moreover it is also declared as haram if the transactions violate the agreement or contain elements of fraud. ${ }^{30}$ Transactions could be done simultaneously although the two parties do not meet because it is via cell phones. However the consent and qabul are immediately as if they are in one place. ${ }^{31}$ After the consent and qabul take place, the seller asks the buyer to transfer money to the seller's bank account. After the money is received, the seller sends the goods to the buyer. Because the physical goods being traded cannot be witnessed directly, only through photo or image, and information about the goods is also through online communication, this selling processand purchase can be ended with ba'i al ghaibala ash shifat (buying and selling of goods that are not presented at the contract assembly or not witnessed in person even though they are present in the assembly, such as buying goods in boxes/boxes, the specifications are only explained through words). Owners of shopping sites on the internet vary, some do sell items that they already own, and some don't have items displayed on their sites. They are only brokers. ${ }^{32}$

A contract in an online buying and selling transaction is different from a direct contract. Electronic transactions usually use a written contract. Selling and buying via electronic media is carried out via modern technology, whose validity depends on the conditions that apply in the sale and purchase. ${ }^{33}$ Ulama implies an assembly in a transaction, except in grants, wills, and wakalah. However, it also implies the continuity of consent and qabul by referring to customs that apply in certain societies. It is just that the ulama of jumhur and the Shafi'iyyah circles is not indicated by the direct word of the qabul, the bidder. If the consent or offer is made or stated in writing or a letter, the qabul must be made or said in the place between the consent and the qabul and there is no indication of denial between the two. ${ }^{34}$ Generally, electronic

${ }^{27}$ Onno Purbo dan Anang Arief Wahyudi, Mengenal e-Commerce (Jakarta: Alex Mediacomputendo, 2000). p. 13.

${ }^{28}$ AzharMuttaqin, Transaksi e-commerce dalam Tinjauan Hukumi Islam (Malang: Lembaga Penelitian Universitas Muhammadiyah, 2009), p. 2.

${ }^{29}$ AzharMuttaqin, Transaksi e-commerce dalam Tinjauan Hukumi Islam, p.4.

${ }^{30}$ M. Abdul Ghoffar E.M, Tafsir Ibnu Katsir Jilid 2 (Bogor: Pustaka Imam AsySyafi'i, 2004), p. 280.

${ }^{31}$ ErwandiTarmizi, Harta Haram Muamalat Kontemporer(Bogor: PT Berkat Mulia Insani, 2017),p. 264.

\footnotetext{
${ }^{32}$ ErwandiTarmizi, Harta Haram Muamalat Kontemporer, p. 265.

${ }^{33}$ Imam Mustofa, FiqihMuamallah Kontemporer, p. 33.

${ }^{34}$ Imam Mustofa, FiqihMuamallah Kontemporer, p. 30.
} 
transactions are carried out in writing. Goods are displayed on internet pages labelled with prices. Consumers or buyers who want to buy transfer money according to the price stated and add shipping costs. ${ }^{35}$

\section{Research Method}

This study is about the muamalah figh contract at the Saga Abepura Mall during the Covid-19 period. This study uses qualitative research based on data from the informant. The data were selected randomly based on the article's theme that fulfilled the research focus criteria, namely obstacles in the process of offline transactions during the Covid-19 period and constraints of consumers in obtaining goods and the MSA managers in distributing products.

This study was conducted in Jayapura City, Papua, in 2020. This location was chosen based on several reasons. First, MSA has so far recommended various activities or transaction activities. Second, MSA is very strategic position of the shopping centre. Third, the quantity of Muslims surrounding the MSA is numerous. The material object of this research is MSA as a forum to meet the needs of the Abepura-Papua people. This study uses two types of data, namely primary data and secondary data. Primary data is based on direct interviews from informants who have been determined. They are the MSA Manager, costumers of MSA, and employees of MSA.

Table 1

The List of Data Sources

\begin{tabular}{|c|l|l|}
\hline No. & Participants & \multicolumn{1}{c|}{ Position } \\
\hline 1. & Rky & Manager of Mall Saga Abepura-Papua \\
\hline 2. & Ibl & The employee of Mall Saga Abepura-Papua \\
\hline 3 & Rsk & The employee of Mall Saga Abepura-Papua \\
\hline 2. & Rhm & Costumer of Mall Saga Abepura-Papua \\
\hline 3. & It & Costumer of Mall Saga Abepura-Papua \\
\hline 4. & Ynt & The employee of Mall Saga Abepura-Papua \\
\hline 5. & Ard & The employee of Mall Saga Abepura-Papua \\
\hline
\end{tabular}

\section{Data Analysis}

The data were collected using normative content analysis techniques. From a technical point of view, content analysis is used to capture normative norms about contract transformation in MSA. In data analysis, researchers use the muamalah fiqh contract approach to see the transactional processes in MSA.

\footnotetext{
${ }^{35}$ Imam Mustofa,FiqihMuamallah Kontemporer, p. 14.
} 


\section{E. Findings and Discussions}

\section{Akad Transformation in Transaction at MSA}

In the concept of contract transformation, transacting in the view of muamalah fiqh is permissible as long as no argument prohibits or is prohibited. It is stated in the rule of Fiqh. ${ }^{36}$

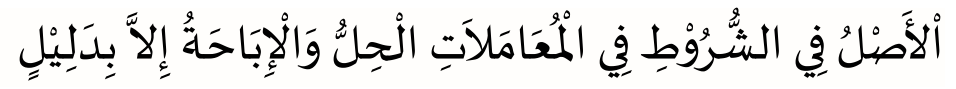

The meaning:

"The original law stipulates the conditions in mu'âmalah are lawful and allowed unless there is evidence (which prohibits it) ",37

$$
\text { الأْ صل فى المعا ملة الإباحة إلا ان يد ل د ليل على تحر يمها }
$$

The meaning:

"The three rules of ushul fiqih have been responded by firman Allah SWT."

Surah An-Nisa', 29:

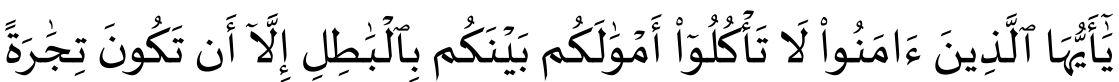

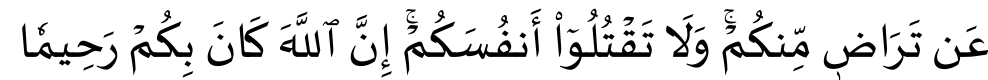

Translation:

"O you who have believed, do not consume one another's wealth unjustly but only (in lawful) business by mutual consent. Furthermore, do not kill yourselves (or one another). Indeed, Allah is to you ever Merciful."

The arguments (dalil) above illustrate that making transactions requires renewal, creation, and innovation, as long as it is not against the Sharia law. Whereas Shara law regulates the application of reform laws, including the sale and purchase agreement and changes in contracts due to the presence of the coronavirus outbreak.

Since the outbreak of the coronavirus in the Abepura-Papua district, the "Mayor of Jayapura" government implemented regulation on social distancing or "stay at home." The President of the Republic of Indonesia, Mr. Joko Widodo, also appealed to school children, civil servants, private employees of shopping centres, and others to temporarily stay at home. As one of Jayapura's three malls, the Mall Saga Abepura continues to experience difficulties in selling its goods. So a strategy is

\footnotetext{
${ }^{36}$ Nawawi, Ismail. FIkihMuamalah Klasik dan Kontemporer; Hukum Perjanjian, Ekonomi, Bisnis dan Sosial (Ghalia Indonesia, Bogor, 2012), p. 143.

${ }^{37}$ See https://almanhaj.or.id/4319

${ }^{38}$ Departemen Agama RI, Al-Qur'an dan Terjemahnya (Jakarta: PT.Kumudasmoro Grafindo Semarang 1994), p. 122.
} 
needed in marketing management, namely transforming the muamalah contract in the form of online buying and selling.

The changing of selling method from offline to online aims to make easier for customers. An online transaction is the preferable method during the Covid-19 period. This option implements a health protocol. It is also a way to keep consumers loyal to MSA, not moving to another place. As Mr. Ibl said, MSA carried out this modelling maintaining MSA's financial stability so that "in July 2020" MSA's finances were stable. This case was proven by the MSA employees who were laid off.

Changing the muamalah contract to the online method must have muamalah principles. Dewi said that the change is fast and spectacular and will be assimilated with others, namely the emergence of technology in people's lives. ${ }^{39}$ According to Anthony Antoniades(1990), transformation is changing gradually so that it reaches the ultimate stage. ${ }^{40}$

To trigger the transformation of online commerce at MSA are external and internal factors. MSA's internal factors are conventional commerce, infrastructure, "goods and services" products and employees at MSA. The MSA manager stated, "The outbreak of the coronavirus (covid-19) givesa tremendous impact on Jayapura's city, in particular, the Abepura district. The Saga Abepura Mall has also reduced consumers so that the income decreased up to $50 \% .{ }^{41}$

Therefore, MSA's offline commerce is less supportive because consumers fear leaving the house over the covid-19 outbreak. Social distancing regulation and time restrictions on shopping and infrastructure cause it. "The location (dept. store and supermarket) of MSA has not changed before and after Covid-19. This case harms our services. Consumers undergo health protocol checks, namely checking body temperature, masks, and washing hands (Rky; 30 years). ${ }^{42}$ Limited space and the implementation of health protocols create long queues. Thus, improvement of employee resources (SDK) must be done. Rsk said, "As an employee in the supermarket section, I have an additional task: promoting products using social media. They use Facebook and Whatsapp. ${ }^{43}$

The data above are external factors in the transformation of an offline contract to online contracts at MSA. The spread of Covid-19 in the city of Jayapura-Abepura began on March 20, 2020was followed by various health protocols. Due to the decrease of the customers, MSA made various innovations in transactions during the Covid-19. The further innovation is"delivery services".Delivery services help

${ }^{39}$ Ernita Dewi, "Transformasi Sosial dan Nilai Agama”, Substantia, 14. no. 1. (April 2012), p. 115.

${ }^{40}$ Anthony C. Antoniades, Poetics of Architecture (New York: Van Nostrand Reinhold, 1990), p. 34. 26 Juli 2020

${ }^{41}$ Rky (Pria, 37 Tahun, Manager Mall Saga Abepura), wawancara, Abepura-Papua, 26 Juli 2020

${ }^{42}$ Rky (Pria, 37 Tahun, Manager Mall Saga Abepura), wawancara, Abepura-Papua,

${ }^{43}$ Riska (Perempuan, 39 Tahun, Karyawan Mall Saga Abepura), wawancara, Abepura-Papua, 26 Juli 2020 
consumers and save the costs. Mostly they use Facebook and Whatsapp applications. However they also face difficulties, mainly when the network is not stableand data packets run out. It, a customer mentioned that she does not use payment online via MSA account but pay it castly (Rhm: 35 years). ${ }^{44}$

According to Rky (MSA manager), each employee is appointed directly by the manager to sell via Facebook and Whatsapp. Then the employee displays the products. Then they offer "delivery" services. If the customer prefers to have a delivery service, there is an additional "cost". The additional costs vary. It is around Rp. 10.000 inside the Abepura district, and Rp. 15,000.00 to Heram district. The product payment process can be paid on the spot according to the "shopping receipt," or through an MSA account by showing proof of transfer. ${ }^{45}$

In the application of muamalah fiqh, contract transparency is required, either in the form of the oral or written agreement. The delivery is carried out twice a day. The conditions are as follows:

a. Online buying and selling services using Facebook and WhatsApp applications.

b. Damaged goods can be returned or exchanged for other products that have similar value.

c. The time limit for complaints is only two days with evidence.

d. The price of "goods" products can be paid through a "from delivery" account or in cash on the spot. And additional delivery fees (delivery services).

Changing the contract in muamalah is allowed by looking at the benefit and the principles of benefit. As Ynt mentions, "I am an MSA employee and I get additional assignments as delivery. I feel happy. My pleasure is getting additional income. One day I can deliver ten times. Then I can get an additional Rp. 120,000 per day. In a month sometimes I get Rp. 1,500,000-. The results are uncertain, depending on the order. Not only me, other friends also become a delivery. ${ }^{46}$ Budi said a different statement that as a delivery service, sometimes the payment is not appropriate. It should be Rp. 15,000, but some customers give Rp. 10,000. But I accept it. ${ }^{47}$

\section{The Online Commerce Produces a New Akad "Order" at MSA}

The buying and selling concept is called offline buying and selling because it does not use media intermediaries. This buying and selling concept is also applied in MSA for micro and macro consumers. Meanwhile, online buying and selling transactions are mediated by the media. Buying and selling online is called e-

\footnotetext{
${ }^{44}$ Rahma (Perempuan, 35 Tahun, pelanggang Mall Saga Abepura), wawancara, Abepura-Papua, 28 Juli 2020 26 Juli 2020

${ }^{45}$ Rky (Pria, 37 Tahun, Manager Mall Saga Abepura), wawancara, Abepura-Papua,

${ }^{46}$ Yanto (Pria, 40 Tahun, Karyawan Mall Saga Abepura), wawancara, AbepuraPapua, 26 Juli 2020 26 Juli 2020

${ }^{47}$ Ardi(Pria, 38 Tahun, Karyawan Mall Saga Abepura), wawancara, Abepura-Papua,
} 
commerce.$^{48}$ According to Onno W Purbo and Anang Arief Wahyudi, buying and selling online is called e-commerce. ${ }^{49}$ Jony Wong said e-commerce is the purchase, sale, and problems of goods and services through an electronic system. E-commerce includes an electronic transfer of funds, exchange, and data collection. All are managed in automatic inventory management. ${ }^{50}$

It can be concluded that buying and selling online is buying and selling using electronic media. Azhar Muttaqin adds that e-commerce is divided into two segments: business to business e-commerce (trading between business actors) and business to consumer e-commerce (trading between business actors and consumers). ${ }^{51}$

The transaction process at MSA is business to business e-commerce. As happened in MSA, products or goods that have been handed over "received by consumers" cannot be returned unless goods or products are damaged or do not fit with the order. The time limit to complain is only two days. Disagreements with the product or ordered items can be submitted via Facebook or WhatsApp.

Even though e-commerce goods have been explained in detail, there is a risk of incompatibility. Therefore, in this transaction, the buyer has a right to return the goods and receive payment or exchange. In this case, the concept of return and exchange rights is in line with the concept of khiyar in Islam.

The practise of buying and selling online has advantages. First, buyers do not need to come to MSA to get goods. They just need to be connected to the internet, select goods, and the goods will be delivered. Second, it saves time and transportation costs because all groceries can be ordered through the internet. Third, the product choices are very, so that consumers can compare all products and prices offered in other malls. As explained by Andi, via the internet, buyers can buy goods at any time. Furthermore, the prices offered are competitive. Thus, the advantages of buying and selling online can increase income in MSA. ${ }^{52}$

a. Buying and Selling of Salam

Buying and selling with an order system is known as salam or salaf, namely, payment in advance, while goods are delivered later. There are three pillars about salam. First, the existence of sighah "consent and kabul". Second, the parties who have contracted. Third, goods and money in exchange for money in goods. Meanwhile, the salam sale and purchase terms are as follows: First, the type of the goods must be clear. Second, the nature of the goods must be clear. Third, the level or size of the goods must be clear. Fourth, the time period for ordering the goods must be clear. Fifth, the assumed capital issued must be known by each party. ${ }^{53}$ Thus, the sale

${ }^{48}$ Imam Mustofa, Fiqih Muamallah Kontemporer, p. 32.

${ }^{49}$ Onno W Purbo dan Anang Arief Wahyudi.Mengenal e-Commerce (Jakarta: Alex Media computendo, 2000), p. 13.

${ }^{50}$ Wong Jony, Internet Marketing for the Beginer (Jakarta: Kompas Gramedia, 2010),p. 23

${ }^{51}$ Azhar Muttaqin, Transaksi e-commerce dalam Tinjauan Hukumi Islam, p.2.

${ }^{52}$ Andi Sunarto, Seluk Beluk E-Commerce (Yogyakarta: Gaya Ilmu, 2009), p. 34.

${ }^{53}$ Imam Mustofa, 2016. p. 88. 
and purchase contract description present a new contract, namely the salam contract As for the salam contract, the sale and purchase are carried out between the seller and the buyer through the order and the payment is made at the beginning. The pillars and terms of the salam buying and selling contract have been carried out by employees, managers, and consumers when consumers order goods from employees. They have met the principles and conditions.

\section{b. Buying and Selling of Istisna}

Etymologically, istisna comes from the word shana'a which means to make something from essential ingredients. The word shana'a- yashna'u gets the suffix hamzah and $t a^{\prime}$ to become the word istisna' -yastisna'. Istisna'means asking or begging for things to be made. The terminology of istisna' means asking someone to make sure goods with individual specifications. Istisna' is also defined as a contract to buy goods that will be made by someone. This Istina' can occur with consent from the customer and an agreement from the order recipient. ${ }^{54}$

There is also a legal basis for istisna'. According to the Hanafiyah ulamah, qiyas and general principles do not allow istisna'. According to him istisna' is the sale and purchase of goods that do not yet exist (bay'ul ma'dum). So it is prohibited by the Prophet. Meanwhile, Imam Malik, Syafi 'I, and Ahmad argued that istisna' was allowed because the Prophet had ordered a ring and a pulpit.

There are several things that need to be considered in the istisna' contract. First, the ownership of the "object". Second, before the goods ordered are finished, the istisna' contract is not binding. Third, the party receiving the order comes with an item to the customer. Then the recipient of the order does not have the right of khiyar because he automatically gives the goods to the customer. ${ }^{55}$

Meanwhile, Imam Hanafiyah requires three things so that the istisna 'is valid. First, the goods that becomes the object of istisna' must be clear, whether in type, kind, content, and nature. Second, the goods ordered are commonly used for purposes and are commonly used, such as clothes, home furnishings, furniture, and so on. Third, it is not allowed to determine and ensure a certain time to deliver the ordered goods. If the time for submission has been determined, it is categorized as a salam contract. At MSA, the istisna contract has been effected since the existence of Covid19. Thus the istisna contract practice has fulfilled the pillars and conditions.

\section{F. Conclusion}

It turns out that the Covid-19 pandemic, which has been considered to bring disaster to the continuity of businesses, does not happen in the Saga Abepura Mall. This study's findings show that the changing from offline to online commerce at MSA brings fortunes with the presence of a new contract, namely, the "order" contract (salam contract and istisnah contract).

\footnotetext{
${ }^{54}$ Imam Mustofa. Fiqih Muamalah Kontemporer. (Jakarta, RajaGrafindoPersada,
} 2012), p. 94.

${ }^{55}$ Imam Mustofa. Fiqih Muamalah Konteporer, p. 95. 
The changing gives benefits: 1 . MSA does not experience financial problems and employee reductions. 2. employees get additional income through delivery services. 3. MSA customers can easily access MSA products through the WhatsApp and Facebook applications. Moreover, the changing of contract from the perspective of muamalah figh in MSA is allowed. Changing the contract can be justified as long as it does not contradict to the al-Qur'an and al-Hadith and benefits people. As stated earlier, muamalah fiqh's origin is permissible to "change" as long as there is no argument against it. It is different from "makdah" worship as long as forbidden worship: haram.

This study is limited to the perspective of contract transformation, namely, order contracts. It does not integrate with other agreements such as borrowing contracts, leasing, accounts payable, and cooperation agreements. These agreements are also very central to business development at MSA. Integrating other contractual perspectives with the contract order perspective allows a comprehensive discussion to be obtained. This method allows further study of new laws in muamalah fiqh during a pandemic. In line with that, further research is needed involving the perspectives of other covenants at MSA.

This article recommends developing the experiences and problems faced by consumers and MSA managers in transacting during the Covid-19 pandemic. In this way, a comprehensive solution is possible. Moreover, the stakeholders in the city of Jayapura-Papua, such as the Papua Province Indonesian Ulema Council (MUI), the trade service government, and businessmen, should be more aware of the transformation of contracts in transactions in Jayapura city and especially AbepuraPapua.

\section{BIBLIOGRAPHY}

Agus Purwanto dkk. "Studi Eksploratif Dampak Pandemi Covid-19 Terhadaap Proses Pembelajaran Online Di Sekolah Dasar." EduPsyCouns Jurnal Kajian Education, Pyschologi and Consuling 2, no. 2 (2020): 1.

Al-ZuhailyWahbah. Al-Fiqh Al-Islamiwa Adillatuh. Damaskus, 2005.

Ali, Muhammad Daud. Hukum Islam. Jakarta: Raja GrafindoPersada, 2004.

Anthony C. Antoniades. Poetics of Architecture. Edited by Van Nostrand Reinhold. New York, 2019.

Anthony C. Poetics of Architecture. New York, 1990.

Ard“Wawancara, Abepura-Papua, 26 Juli,” 2020. 
Asep Rozali. "Transformasi Akad Perbankan Syariah Dalam Pembentukan Hukum Perikatan Nasional.” Wawasan Yuridika 4, no. 1 (2019): 31.

Azhar Muttaqin. Transaksi E-Commerce Dalam Tinjauan Hukumi Islam. Malang: Lembaga Penelitian UniversIts Muhammadiyah, 2009.

AzharMuttaqin. Transaksi E-Commerce Dalam Tinjauan Hukumi Islam, n.d.

Aziz, Jamal Abdul. “Transformasi Akad Bay’ al-Murabah dari Konsep Fikih ke Produk Bank (Analisis Kritis Perspektif Fikih Muamalah)”, Al-Manahij: Jurnal Kajian Hukum Islam, IAIN Purwokerto, Vol. 8 No. 2, 2014

Dedy Ansari Harahap. "Perilaku Belanja Online Di Indonesia: Studi Kasus." JRMSI 9, no. 2 (2018): 34.

Departemen Agama RI. Al-Qur'an Dan Terjemahnya. Jakarta: PT.Kumudasmoro Grafindo Semarang, 1994.

Eka AviantiAyuningtyas. "Dampak Pandemi Covid-19 Terhadap Bisnis dan Eksistensi Platform Online.” Pengembangan Wiraswasta 22, no. 1 (2020): 23.

ErnIt Dewi. ““"Transformasi Sosial dan Nilai Agama.” Substantia 14, no. 1 (2012): 115.

Erwandi Tarmizi. Harta Haram Muamalat Kontemporer. Bogor: PT Berkat Mulia Insani, 2017.

Habraken, N. J. Transformation of the Site. Walter Press: Cambridge, 1983.

Hanoatubun, Silpa. "Dampak Covid-19 Terhadap Perekonomian Indonesia." EduPsyCouns 2, no. 1 (2020): 45.

Haroen, Nasrun. "Hukum Jual Beli Dalan Islam.”

Hasbi al-Shiddiqy. Hukun-Hukum Fiqh Islam. Semarang: Pustaka Rizki Putera: Pustaka Rizki Putera, 1997.

HendiSuhend. Fiqh Muamalah. Jakarta: PT. Raja GrafindoPersada, 1997.

Ikbal"Wawancara, Abepura-Papua," 2020.

Imam Mustofa. Fiqih Muamallah Kontemporer. Jakarta: PT.GrafendoPersada, 2016.

Indra Rhmtullah. "Jaminan Hak Kesehatan Pekerja Work From Office Selama Masa PSBB Covid-19.” Andalah: Buletin Hukum \& Keadilan 4, no. 1 (2020): 57.

Ismail Nawawi. FIkih Muamalah Klasik dan Kontemporer; Hukum Perjanjian, Ekonomi, Bisnis Dan Sosial. Ghalia Indonesia: Bogor: Ghalia Indonesia, 2012.

It "Wawancara Karyawan Mall Saga Abepura," 2020.

LarasatiDhinarti, dan FirdaAmalia. "“E-Commerce Dalam Perspektif Fiqh Muamalat." CIMAE 2, no. 3 (2019): 162.

M. Abdul Ghoffar E.M. Tafsir Ibnu Katsir Jilid 2. Bogor: Pustaka Imam Asy-Syafi', 2004.

Nawawi, Ismail. Fikih Muamalah Klasik dan Kontemporer; Hukum Perjanjian, 
Ekonomi, Bisnis Dan Sosial. Ghalia Indonesia, Bogor, 2012.

Nurhayati. "Belanja Online Sebagai Cara Belanja Di Kalangan Mahasiswa (Studi Kajian Budaya di UniversIts Malikussaleh, Lhokseumawe, Aceh)." Anthropological 1, no. 2 (2017).

Onnow Purbo, Anang Arief Wahyudi. Mengenal E-Commerce. Jakarta: Alex MediaComputendo, 2000.

Rhm "Wawancara, Abepura-Papua, 28 Juli,” 2020.

Rsk“Wawancara, Abepura-Papua, 26 Juli 2020,” 2020.

Rky“Wawancara, Abepura-Papua, 26 Juli,” 2020.

SayyidSabiq. Fiqh Al-Sunnah. Edited by Dar al-FathLali'lami al-Arabi. Qahirah, 1990.

Stephanie Jill Najoan. “Transformasi Sebagai Strategi Desain.” Media Matrasain 8, no. 2 (2011): 119-120.

Sunarto, Andi. Seluk Beluk E-Commerce, 2009.

Timur, Tribun. "Update-Virus-Corona-Di-Papua-Dan-Papua-Barat." Last modified 2020. https://papua.tribunnews.com.

Wong Jony. Internet Marketing for the Beginer. Jakarta: Kompas Gramedia, 2010.

Ynt“Wawancara, Abepura-Papua, 26 Juli,” 2020.

Yusuf, Sofie. Pelaku Usaha Konsumen dan Tindak Pidana Korporasi, n.d.

"BerIt/Umar-Bin-Khattab-Usir-Pedagang-Yang-Tak-Paham-Fiqih-Muamalat."

"Https:/Republika.Co.Id/BerIt/Qcq4ub430.” Last modified 2020. https://republika.co.id.

"Https://Ummaspul,e-Journal.Id/Edupsycouns/Article/View/423." 


\section{Guidelines}

\section{Submission of Article}

urnal Adabiyah welcomes the articles submission with the main themes on Humanities and Islamic Studies with the emphasis on interdisciplinary and intertextuality approach. Adabiyah is thematicly published twice in a year. ie the theme of the humanities in June and the Islamic Study in December.

Themes related to Islamic Studies are textual studies, scriptural traditions, Islamic law, and theology; and those related to Humanities are language, literature, history, and culture. This scholarly journal Guarantees that the editor decision based on the peer review results will not exceed 30 days from the paper submission date.

Authors are invited to read our archives; to find the relevant topics for the journal, and to submit complete unpublished scientific researches, which are not under review in any other conferences or academic journal.

\section{PUBLICATION ETHIC}

Publication Ethic and Malpractice Statement

Jurnal Adabiyah is a peer-reviewed journal, published twice a year by the Faculty of Adab and Humaniora, Alauddin State Islamic University of Makassar Indonesia. It is available online as open access sources as well as in print. This statement clarifies ethical behaviour of all parties involved in the act of publishing an article in this journal, including the author, the editor-in-chief, the Editorial Board, the reviewers, and the publisher. This statement is based on COPE's Best Practice Guidelines for Journal Editors.

Ethical Guideline for Journal Publication

The publication of an article in Jurnal Adabiyah, is an essential building block in the development of a coherent and respected network of knowledge. It is a direct reflection of the quality of the work of the authors and the institutions that support them. Peer-reviewed articles support and embody the scientific methods. It is therefore important to agree upon standards of expected ethical behavior for all parties involved in the act of publishing: the author, the editor, the reviewer, the publisher, and the society. As the publisher of Jurnal Adabiyah, the Faculty of Adab and Humaniora takes its duties of guardianship over all stages of publishing seriously and it recognizes its ethical and other responsibilities. The Faculty of Adab and Humaniora committed to ensuring that advertising, reprint or other commercial revenue has no impact or influence on editorial decisions.

\section{Publication Decisions}

The editors of Jurnal Adabiyah is responsible for deciding which articles submitted to the journal should be published. The validation of the work in question and its importance to researchers and readers must always drive such decisions. The editors may be guided by the policies of the journal's editorial board and constrained by such legal requirements as shall then be in force regarding libel, copyright infringement, and plagiarism. The editors may confer with other editors or reviewers in making their decisions.

\section{Plagiarism Screening}

It is basically author's duty to only submit a manuscript that is free from plagiarism and academically malpractices. The editor, however, will check all submitted papers through Turnitin.

\section{Fair Play}

An editor at any time evaluates manuscripts for their intellectual content without regard to race, gender, sexual orientation, religious belief, ethnic origin, citizenship, or political philosophy of the authors. 


\section{Confidentiality}

The editors and any editorial staff must not disclose any information about a submitted manuscript to anyone other than the corresponding author, reviewers, potential reviewers, other editorial advisers, and the publisher, as appropriate.

\section{Disclosure and Conflicts of Interest}

Unpublished materials disclosed in a submitted manuscript must not be used in editors' own research without the express written consent of the author.

\section{DUTIES OF AUTHORS}

\section{Reporting Standards}

Authors of reports of original research should present an accurate account of the work performed as well as an objective discussion of its significance. Underlying data should be represented accurately in the paper. A paper should contain sufficient detail and references to permit others to replicate the work. Fraudulent or knowingly inaccurate statements constitute unethical behaviour and are unacceptable.

\section{Originality and Plagiarism}

The authors should ensure that they have written entirely original works, and if the authors have used the work and/or words of others that this has been appropriately cited or quoted.

\section{Multiple, Redundant, or Concurrent Publication}

An author should not in general publish manuscripts describing essentially the same research in more than one journal or primary publication. Submitting the same manuscript to more than one journal concurrently constitutes unethical publishing behaviour and is unacceptable.

\section{Acknowledgement of Sources}

Proper acknowledgment of the work of others must always be given. Authors should cite publications that have been influential in determining the nature of the reported work.

\section{Authorship of the Paper}

Authorship should be limited to those who have made a significant contribution to the conception, design, execution, or interpretation of the reported research. All those who have made significant contributions should be listed as co-authors. Where there are others who have participated in certain substantive aspects of the research project, they should be acknowledged or listed as contributors. The corresponding author should ensure that all appropriate co-authors and no inappropriate co-authors are included on the paper, and that all co-authors have seen and approved the final version of the paper and have agreed to its submission for publication.

\section{Disclosure and Conflicts of Interest}

All authors should disclose in their manuscript any financial or other substantive conflict of interest that might be construed to influence the results or interpretation of their manuscript. All sources of financial support for the project should be disclosed.

\section{Fundamental errors in Published Works}

When an author discovers a significant error or inaccuracy in his/her own published work, it is the author's obligation to promptly notify the journal editor or publisher and cooperate with the editor to retract or correct the paper.

\section{PLAGIARISMIE}

It is basically author's duty to only submit a manuscript that is free from plagiarism and academically malpractices. The editor, however, will check all submitted papers through Turnitin. 


\section{AUTHOR GUIDELINES}

\section{Guidelines for online submission:}

1. Author should first register as Author to the website of Jurnal Adabiyah. Click the menu "register" to register as an author.

2. Once after the author is registered, please login to the website of Jurnal Adabiyah and submit the article through online submission (with the stat us of active submissions).

3. The article should follow the standard template of Jurnal Adabiyah provided in the website.

4. The citation and bibliography should follow the Turabian citation style.

5. Author is restricted not to send his/her article to another journal before having confirmation from the editorial team (approximately 4 weeks right after the article submitted).

6. Author should follow editorial decisions and recommendations related to the article completion. All reviews and assessements will be informed through online submission.

Article submitted to Jurnal Adabiyah editorial board must follow these guidelines:

1. Article should be based on the scientific research in the field humanities and Islamic studies;

2. Article must be an original work and has not been previously published;

3. Article should be written in Arabic or English languages;

4. Article must be typed in one-half spaced on A4-paper size;

5. Article's length is about $6,000-10,000$ words;

6. All submission must include a 150-250 word abstract;

7. Abstract should be written in 3 languages; Arabic, English, and Bahasa;

8. Full name(s) of the author(s) must be stated, along with his/her/their institution and complete address;

9. All submission should be in OpenOffice, Microsoft Word, RTF, or WordPerfect document file format;

10. Bibliographical reference must be noted in footnote and bibliography according to Jurnal Adabiyah style. In addition, it is suggested for author(s) to use reference manager tools such

\section{as MENDELEY or 7 otero}

When a source is cited for the first time, full information is provided: full name(s) of author(s), title of the source in italic, place of publication, publishing company, date of publication, and the precise page that is cited. For the following citations of the same source, list the author's last name, two or three words of the title, and the specific page number(s). The word ibid., op.cit., and loc.cit. are may not be used any more.

\section{Example in footnotes:}

${ }^{1}$ Mircea Eliade (ed.), The Encyclopedia of Religion, vol. 8 (New York: Simon and Schuster, 1995), h. 18.

${ }^{2}$ Norman Daniel, Islam and the West (Oxford: One World Publications, 1991), h. 190.

${ }^{3}$ Syeikh Ja'far Subhāni, Mafăhim Al-Qur'ān (Beirut: Mu'assasah Al-Tarīkh Al-'Arabī, 2010)., Juz 5, h. 231. 
${ }^{4}$ Syeikh Ja'far Subhānī, Mafāhim Al-Qur'ān, h. 8-9.

\section{Example in bibliography:}

Subhānī, Syeikh Ja'far. Mafăhim Al-Qur'ān. Beirut: Mu'assasah Al-Tarīkh Al-’Arabī, 2010.

Eliade, Mircea (ed.). The Encyclopedia of Religion, vol. 8. New York: Simon and Schuster, 1995.

Daniel, Norman. Islam and the West. Oxford: One World Publications, 1991.

Shihab, Muhammad Quraish. Sunnah-Syiah Bergandengan Tangan: Mungkinkah? Kajian Atas Konsep Ajaran Dan Pemikiran. Cet. III. Jakarta: Lentera Hati, 2007.

\section{Detail informations of the footnotes:}

1. Holy book

Al-Qur'ân, Al-Baqarah/2: 185.

Perjanjian Baru, Mrk. 2: 18.

2. Qur'anic translation

${ }^{1}$ Departemen Agama RI, al-Qur'an dan Terjemahannya (Jakarta: Darus Sunnah, 2005), h. 55.

3. Book

${ }^{1}$ Muḥammad 'Ajjaj al-Khațib, Ușl al-Hadith: 'Ulumuh wa Mușțalaḥ uh (Beirut: Dâr al-Fikr, 1989), h. 57.

4. Translation Books

${ }^{1}$ Toshihiko Izutsu, Relasi Tuhan dan Manusia: Pendekatan Semantik terhadap al-Qur'an, terj. Agus Fahri Husein dkk (Yogyakarta: Tiara Wacana, 2003), h. 14.

5. Voluminous book

${ }^{1}$ Muḥammad al-Ṭâhir b. 'Ashur, al-Tahrīir wa al-Tanwīr, Vol. 25 (Tunisia: Dâr al-Suhûn, 2009), h. 76.

${ }^{1}$ Muḥammad b. Ismā‘īl al-Bukharī, al-Jami‘ al-Ṣaḥịh, Vol. 2 (Beirut: Dar al-Kutub al-‘Ilmı́yah, 1999), h. 77.

6. Article in book

${ }^{1}$ Sahiron Syamsuddin, "Metode Intratekstualitas Muhammad Shahrur dalam Penafsiran al-Qur'an" dalam Abdul Mustaqim dan Sahiron Syamsuddin (eds.), Studi al-Qur'an Kontemporer: Wacana Baru Berbagai Metodologi Tafsir (Yogyakarta: Tiara Wacana, 2002), h. 139.

7. Article in encyclopaedia

${ }^{1}$ M. Th. Houtsma, "Kufr" dalam A. J. Wensinck, at al. (ed.), First Encyclopaedia of Islam, Vol. 6 (Leiden: E.J. Brill, 1987), h. 244.

8. Article in journal

${ }^{1}$ Muhammad Adlin Sila, "The Festivity of Maulid Nabi in Cikoang, South Sulawesi: Between Remembering and Exaggerating the Spirit of Prophet", Studia Islamika 8, no. 3 (2001): h. 9.

9. Article in mass media

${ }^{1}$ Masdar F. Mas'udi, "Hubungan Agama dan Negara”, Kompas, 7 Agustus 2002. 
10. Article in Internet

${ }^{1}$ Muhammad Shahrūr, "Reading the Religious Teks: a New Approach" dalam http://www.shahrour.org/25 Februari 2010/diakses 5 Juni 2010.

11. Thesis or dissertation

${ }^{1}$ Syahruddin Usman, "KinerjaGuru Penddikan Agama Islam pada SMAN dan SMKN Kota Makassar”, Disertasi (Makassar: PPs UIN Alauddin, 2010), h. 200.

\section{COPYRIGHT NOTICE}

Authors who publish with this journal agree to the following terms:

1) Authors retain copyright and grant the journal right of first publication with the work simultaneously licensed under a Creative Commons Attribution License that allows others to share the work with an acknowledgement of the work's authorship and initial publication in this journal.

2) Authors are able to enter into separate, additional contractual arrangements for the non-exclusive distribution of the journal's published version of the work (e.g., post it to an institutional repository or publish it in a book), with an acknowledgement of its initial publication in this journal.

3)Authors are permitted and encouraged to post their work online (e.g., in institutional repositories or on their website) prior to and during the submission process, as it can lead to productive exchanges, as well as earlier and greater citation of published work (See The Effect of Open Access). 